\title{
Unlocking Pandora's box: personalising cancer cell death in non-small cell lung cancer
}

\author{
Dean A Fennell ${ }^{1,3^{*}}$ and Charles Swanton ${ }^{2,3}$
}

\begin{abstract}
Evasion of apoptosis is a hallmark of tumorigenesis and a recognised cause of multidrug resistance. Over the last decade, insights into how apoptosis might be exploited in non-small cell lung cancer (NSCLC) and how cancer therapeutics might be used to engage apoptotic signalling in a personalised manner have changed markedly. We are now in the wake of a paradigm shift in stratified therapeutic approaches related to NSCLC. At the heart of this shift in thinking is the emerging knowledge that even the most drug-resistant cancers exhibit a functional death pathway and, critically, that this pathway can be efficiently engaged, leading to clinical benefit. This review will summarise current knowledge of mitochondrial apoptotic pathway dysfunction in NSCLC and how the next generation of targeted therapeutics might be used to exploit deficiencies in apoptotic signalling in a personalised manner to improve clinical outcome and predict therapeutic benefit.
\end{abstract}

Keywords: Personalised medicine, Lung cancer, Somatic mutations, Apoptosis, Mitochondria, Targeted therapy

\section{Review}

The mitochondria collectively represent a cellular Pandora's box. The key to effective treatment of non-small cell lung cancer (NSCLC) should be the identification of personalised therapeutic approaches capable of selectively engaging mitochondrial cell death. An approach that holds the greatest promise for achieving this may lie in the use of genetics to identify 'keys to unlock' Pandora's box in NSCLC.

\section{Pandora's box and mitochondrial apoptosis}

The organelles termed mitochondria constitute a major component of the canonical death pathway which initiates apoptosis. During life, these organelles play a critical role in maintaining bioenergetic homeostasis, predominantly through the synthesis of adenosine trisphosphate. However, following a fatal cellular insult, mitochondria commit irreversibility to ensuring the death of the cell. To achieve this, mitochondria release into the cytoplasm deathsignalling proteins, which are normally harboured, safe out of reach, within the intermembrane space or cristae. This occurs as a result of mitochondrial outer membrane

\footnotetext{
* Correspondence: df132@le.ac.uk

'University of Leicester \& Leicester University Hospitals, Hodgkin Building, Lancaster Road, PO Box 138, Leicester LE1 9HN, UK

${ }^{3}$ UCL Cancer Institute, Paul O'Gorman Building, Huntley St, London WC1E, UK Full list of author information is available at the end of the article
}

permeabilisation or MOMP. Upon release, these factors which include cytochrome C [1,2], OMI, smac [3], and apoptosis-inducing factor $[4,5]$ lead to the activation of cellular demolition machinery comprising zymogens termed caspases, which systematically cause the noninflammatory elimination of the cell via apoptosis and immune cell engulfment [6]. MOMP occurs as a result of the activation of proapoptotic BCL2 family proteins.

The multidomain family members BAX and BAK exhibit genetic redundancy and undergo homo- and hetero-oligomerisation $[7,8]$ to promote pore formation in the outer mitochondrial membrane - essentially the key to unlocking Pandora's box [9]. To trigger MOMP, BAX/BAK must first be activated. This requires a subset of proapoptotic BCL2 family proteins which harbour a single BCL-2 homology domain 3 (BH3) [10-13]. This alpha helical amphipathic domain is sufficient to activate BAX and BAK and may do so by two mechanisms. The BH3-only proteins BIM, BID and PUMA directly activate $\mathrm{BAX} / \mathrm{BAK}$, leading to their oligomerisation and MOMP $[14,15]$. BIM is activated by post-translational modification through phosphorylation, causing its stabilisation [16-19]. In contrast, BID is a substrate for caspase 8 cleavage induced by death receptor ligation [20], whereas PUMA is transcriptionally activated [21]. A second group of five BH3-only proteins (BAD, NOXA, 
BNIP3, BFK and BMF) activates BAX and BAK by disrupting their interaction with the prosurvival members of the BCL2 family, which comprise BCL2, BCLXL, MCL1, BCLW and BCLB [22-25]. The apparent redundancy in BH3-only proteins may be explained by their role as functionally distinct cell damage sensors.

\section{Do prosurvival BCL2 proteins 'lock' Pandora's box?}

Prosurvival BCL2 family proteins have long been considered as critical suppressors of apoptosis in cancer. This is supported by their high rate of gene amplification. For example, MCL1 encoded at the 1q21.2 locus frequently exhibits copy number gain in cancer, followed by BCLX (BCLL2) [26]. The basis for this may be as a countermeasure to circumvent the proapoptotic activity of critical oncogenes during transformation. For example, c-mycdriven transformation has been shown to require obligatory upregulation of BCL2 to overcome CD95-mediated apoptosis $[27,28]$. More recently, it has been shown that H-RAS-mediated transformation leads to non-apoptotic cell death through induction of autophagy with upregulation of the BH3-only protein NOXA and disruption of the MCL-1-beclin-1 complex [29]. Overexpression of prosurvival BCL2 family members may therefore reflect a required defence against constitutively generated 'death signals, which would otherwise induce apoptosis. Growing evidence suggests that constitutive activation of $\mathrm{BH} 3$ death signals probably induced by 'insufficient oncogenes' results in addiction to prosurvival BCL2 family proteins. It has been proposed that prosurvival BCL2 members, by forming constitutive complexes with activated BH3-only proteins, are primed for death [30]. Accordingly, BH3 domain peptides, capable of competitively inhibiting heterodimerisation of prosurvival BCL2 family members, can induce apoptosis by freeing BAX and BAK to oligomerise [31]. These BH3-only domains exhibit restricted specificity for prosurvival BCL2 members. For example, NOXA interacts only with MCL1 and A1, whereas BAD interacts with BCL2, BCLXL and BCLW. In contrast, BIM and PUMA are promiscuous in their prosurvival BCL2 protein interactions [32,33].

BH3 peptidomimetics are a new class of drug which were developed to mimic the interaction of $\mathrm{BH} 3$ domains. The prototype inhibitors navitoclax (ABT-263) [34] and ABT-737 were identified as BAD BH3 peptidomimetics using NMR-based screening, with high affinity for BCL2, BCLX and BCLW [35]. ABT-737 is a potent apoptosis sensitiser in preclinical models and can induce the regression of xenografts [36], which are primed for death such as small cell lung cancer. ABT-263 exhibits some evidence of efficacy in the clinical setting [37]; however, in common with other targeted agents, its efficacy may be limited in unselected populations. Identifying which cancers will respond to ABT-263 may be feasible. Because of the prosurvival BCL2 family restriction associated with ABT263/737, there is robust preclinical evidence showing that MCL1 expression is a major resistance factor [38-42]. However, even in the presence of MCL1, ABT737 can exhibit preclinical activity in some cancers such as CLL, possibly due to constitutive occupancy due to priming for death. This possibility is reflected in gene expression analysis, which has shown a correlation between sensitivity and the expression of NOXA [43]. In preclinical models of lung cancer and mesothelioma, cell lines grown in three dimensions acquire apoptosis resistance [44] due to an altered expression of prosurvival BCL2 family members conferring sensitivity to ABT737, and this is associated with priming for death $[45,46]$.

\section{Growth factor suppression of the core apoptosis machinery}

The mitochondrial apoptosis pathway is directly suppressed by survival signalling. BIM expression is regulated by phosphorylation in response to growth factors [16-19,47-50]. This occurs in a mitogen-activated protein kinase kinaseextracellular signal-regulated protein kinase 1/2 (MAPKERK)-dependent manner, leading to its polyubiquitination and destabilisation through proteasomal degradation [16]. The dissociating BH3-only protein BAD is regulated by serine phosphorylation, which causes its inactivation through sequestration to 14-3-3 [51].

The prosurvival BCL2 protein MCL-1 is also regulated by survival signals. The phosphatidylinositol 3-kinase /protein kinase B (PI3K/AKT) pathway, which signals downstream of receptor tyrosine kinases such as the epidermal growth factor receptor, stabilises MCL-1 via AKT signalling. Glycogen synthase kinase 3 (GSK-3) is a substrate for and is inhibited by AKT. Upon growth factor withdrawal, GSK-3 is de-repressed and phosphorylates MCL-1 at S159. This phosphorylation leads to ubiquinylation and degradation of MCL-1 via the proteasome. Collectively therefore, survival and proliferation are driven in parallel with suppression of apoptosis. Recently, it has emerged that dominant survival pathways exist in subsets of NSCLC, which, if targeted, can unleash BH3-only proteins and mediate effective apoptosis both at the bench and at the bedside.

\section{Dominant oncogenes as Achilles' heels for unleashing BH3-only proteins}

Although there is overwhelming evidence now to implicate genomic instability and temporal acquisition of complex somatic gene alterations as causal factors during carcinogenesis, the identification of critical oncogenic drivers has had major implications for the development of therapeutics in NSCLC. The paradigm in this solid tumour mirrors the discovery and targeting of the BCR$\mathrm{ABL}$ fusion protein, the dominant oncogenic driver in 
chronic myelogenous leukaemia [52-55]. Prior to 2004, a therapeutic plateau had been reached in the management of NSCLC. Platinum-based therapy was considered the gold standard with no identifiable superior regimen, associated modest response rates and impact on overall survival [56] even with the addition of novel agents [57,58]. Clinical trials then focused on what was considered a homogeneous NSCLC population. Although this approach led to the approval of the epidermal growth factor receptor tyrosine kinase inhibitor (EGFR TKI) erlotinib in second and third line NSCLC [59,60], this was not reflected in the negative, front-line pivotal phase III trials combining EGFR TKIs gefitinib and irressa with chemotherapy in unselected populations [61-64]. The seminal discovery that a subset of patients harbouring somatic mutations of the EGFR exhibits dramatic responses to the orally bioavailable receptor tyrosine kinase inhibitor gefitinib or erlotinib [65-67] spearheaded the shift in thinking about how to target NSCLC more effectively. The superior efficacy of oral TKI therapy for treating mutant EGFR $\left(E_{G F R}{ }^{M U T}\right)$-positive NSCLC was borne out in pivotal randomised, controlled clinical trials $[68,69]$.

Somatic mutations of EGFR, of which the most common are deletions of exon 19 and nucleotide substitions in exon 21 [70], have been shown to confer an increase in anti-apoptotic signalling capacity [71] and confer a cell survival advantage driving Darwinian selection. $\mathrm{Mu}-$ tation of EGFR causes an increase in enzyme activity and suppression of autoinhibitory function [72] and confers resistance to conventional cytotoxic drugs [71]. Inhibition leads to dramatic activation of apoptosis via the mitochondrial pathway [73] involving activation of BIM in common with the apoptosis that results following the inhibition of bcr-abl kinase in CML [55,74]; this is consistent with a common link between driver oncogene addiction, survival and suppression of critical death signals.

Upon inhibition of EGFR ${ }^{\mathrm{MUT}}$, there is a dramatic increase in the level of BIM through transcriptional and post-translational mechanisms (Figure 1). Activation of BIM requires the MAPK-ERK signalling pathway, but not JNK nor PI3K/AKT signalling. Silencing this BH3only protein alone effectively rescues from EGFR ${ }^{\mathrm{MUT}}$ inhibition in vitro and in vivo [75-78]. ABT-737 confers sensitivity to erlotinib in EGFR ${ }^{\mathrm{MUT}}$ cells $[75,77]$, implicating a potential for BH3 peptidomimetics as enhancers of EGFR TKIs efficacy in common with BIM-mediated apoptosis in bcr-abl-inhibited CML [55]. However, one caveat to this approach could be the rapidly emerging resistance and failure to activate critical death signals.

\section{BIM mediates apoptosis following ALK inhibitor in EML4- ALK-rearranged NSCLCs}

Within 3 years of the initial discovery of EGFR ${ }^{\mathrm{MUT}}$ addiction in NSCLC, a small proportion of NSCLCs (around $4 \%$ to $6 \%$ ) was reported to harbour a small inversion within chromosome $2 \mathrm{p}$, resulting in the fusion of the echinoderm microtubule-associated protein-like 4 (EML4) gene and the anaplastic lymphoma kinase (ALK) gene. As with EGFR ${ }^{\mathrm{MUT}}$ NSCLC, these NSCLCs are restricted to a specific histological subset of NSCLCs, namely non-squamous tumours. Consistent with EML4ALK being a driver mutation, NSCLCs harbouring this gene rearrangement are mutually exclusive of EGFR or KRAS mutations. The mechanism underlying induction of apoptosis following inhibition of ALK involves the upregulation of BIM and downregulation of the inhibitor of apoptosis protein survivin [79]. EML4-ALK drives the ERK pathway, and this is involved in the suppression of BIM, in contrast to surviving which is regulated by the STAT pathway in response to EML4-ALK. Consequently, targeting EML4-ALK appears to induce apoptosis, in common with EGFR inhibition, through activation of intrinsic mitochondrial pathway. Based on the dramatic responses seen in the clinical setting [80], the ALK inhibitor crizotinib (PF-02341066) received approval in record time [80].

\section{Resistance to targeted therapies through emergent secondary mutations blocks apoptosis}

In the case of mutant EGFR, clinical efficacy is frequently limited by secondary mutation. The most commonly described mutation T790M $[81,82]$, which can also be transmitted in the germline, is also a susceptibility allele $[83,84]$. T790M is present as a minor clone in NSCLC $[85,86]$ and may be selected for during therapy [87]. This mutation has been shown to prevent the activation of BIM in response to gefitinib but can be overcome by an irreversible inhibitor of EGFR [76]. Other critical resistance mechanisms have been identified to be linked to the inhibition of EGFR ${ }^{\mathrm{MUT}}$ and include MET amplification [88-91], PTEN loss [92], HER2 kinase domain [93] or PIK3CA, and transformation to small cell lung cancer [87]. Selection pressure mediated by dramatic apoptosis induction drives the emergence of resistant clones capable of abrograting apoptosis signalling. Strategies to overcome this problem include structure-based modelling and discovery of bona fide T790M EGFR-targeting inhibitors [94]. Bypassing the EGFR altogether and target downstream pathways is another possibility. Survival signals from EGFR diverge through the PI3K/AKT and MAPK/ERK pathways. In EGFR ${ }^{\mathrm{MUT}}$ cell lines, inhibition of PI3K/AKT pathway leads to selective downregulation of MCL-1. In contrast, inhibition of the MAPK/ERK pathway leads to BIM upregulation. Combining PI3K and MEK inhibition may therefore present a strategy for overcoming resistance [95], as might targeting dependence on NF kappa B, which has been identified by RNAi screening in the context of $\mathrm{EGFR}^{\mathrm{MUT}}$ [96]. 


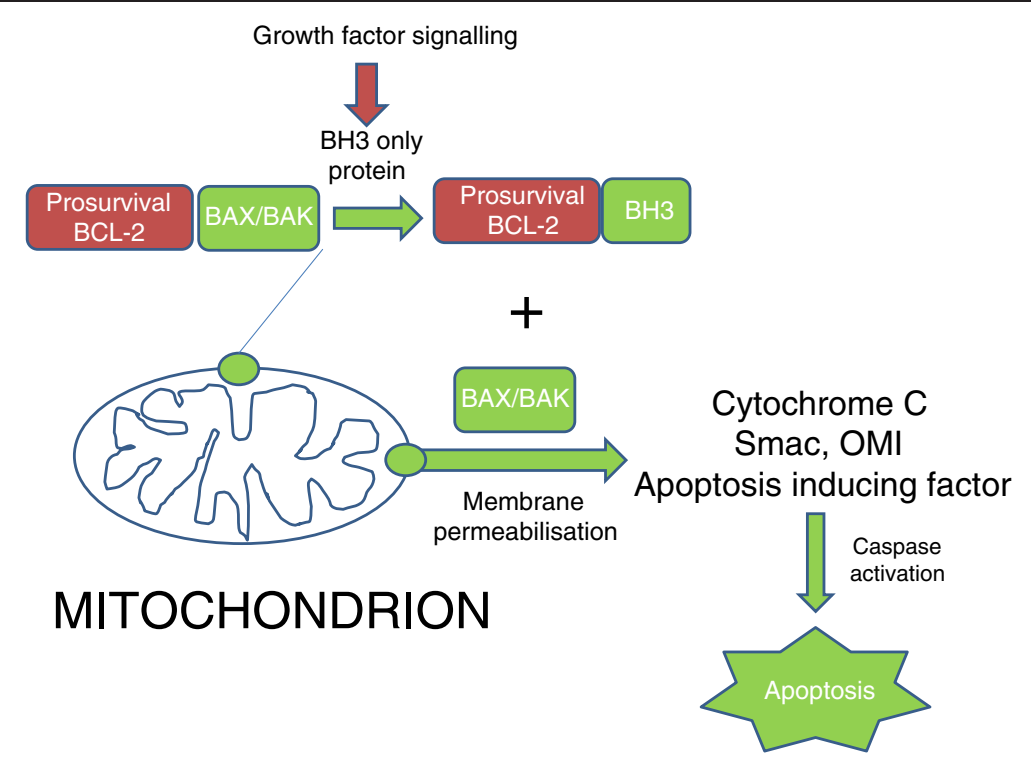

Figure 1 Mitochondrial apoptosis pathway. Mitochondria are effectors for cell death following inhibition of growth factor-addicted survival pathways linked to somatic oncogene mutations (eg., EGFR). BH3-only proteins are unleashed and lead to the activation of the mitochondrial apoptosis pathway. Proapoptotic signalling is indicated in green, anti-apoptotic in red.

In common with resistance mechanisms identified for EGFR (and indeed bcr-abl), ALK-rearranged cancers have been reported to develop secondary mutations [97,98]. Rearranged ALK is relatively unstable and is dependent upon heatshock protein 90 to prevent its spontaneous ubiquitination and targeting to the proteasome for degradation. Inhibition of the chaperone, heatshock protein 90 (HSP90), leads to a downregulation of EML4 ALK and inhibition of signalling even in the presence of secondary mutations, suggesting that this might be a potential strategy for overcoming resistance [99-101]. As with EGFR, structure-based modelling has potential to identify smallmolecule inhibitors capable of overcoming resistance due to gatekeeper mutation of ALK [102].

\section{Personalising NSCLC therapy: towards identifying the full complement of oncogenic drivers in NSCLC}

Beyond EGFR and ALK rearrangement, several additional somatic gene alterations linked to oncogenic drivers have been and are continued to be identified across the genomic landscape of NSCLC. As with the prototypical somatic mutations in EGFR and ALK, many of these may provide real opportunities for achieving similarly dramatic therapeutic outcomes. Sequencing efforts have identified mutations of KRAS, B-RAF, Her2/erbb2, PIKC3A, LKB1 and MET amplification [103-105]. These commonly occurring mutations can be screened in a clinical-practice-based setting to enable personalised therapy to be most effectively delivered [106]. For many or all of these oncogenic drivers, inhibition of the dominant signalling pathway may trigger BIM-dependent apoptosis, as shown for mutant B-RAF [107-109], Her2 [110] and MET amplification. KRAS is frequently mutated in around a quarter of NSCLCs, and its activation causes lung cancer in mice [111]. It has been widely recognised as a hard target to drug [112]. However, this situation is changing. For example, C-RAF, but not BRAF, has been identified through gene ablation studies, and TBK1 through RNAi screening, to be essential for KRAS-dependent NSCLC. Stability of mutant KRAS may depend on HSP90 [113-115], implicating this chaperone as a potential molecular target. Finally, novel specific inhibitors of KRAS have been identified.

There have been rapid advances in genome sequencing technology, which now provide an opportunity to systematically interrogate somatic gene alterations in NSCLC [116,117]. The International Cancer Genome Consortium has been developed to do this in NSCLC and 49 other cancers [118]. With this technological development, it is likely that there will be the ability to comprehensively annotate the full complement of somatic gene alterations involved in driving NSCLC. The translational implications for personalised therapeutics and predictive biomarker development are clear based on the previous successes: that early identification of these oncogenic drivers will reflect vulnerabilities that will allow stratification of patients to receive the appropriate and effective apoptosis-inducing therapy.

\section{Conclusions}

The induction of apoptosis has long been cited as a key objective for achieving drug-induced tumour suppression; 
however, evasion of this process has equally been known to limit the efficacy of conventional treatments. Now, in this era of genomics, it is clear that personalising drug therapy to most effectively target addiction to growth factor signalling pathways, by virtue of somatic mutations, provides a new exciting therapeutic opportunity, at least for initial disease control. However, combating resistance even in this era will present a major new challenge.

\section{Competing interests}

The authors declare that they have no competing interests.

\section{Author details}

'University of Leicester \& Leicester University Hospitals, Hodgkin Building, Lancaster Road, PO Box 138, Leicester LE1 9HN, UK. ${ }^{2}$ Cancer Research UK London Research Institute, Translational Cancer Therapeutics Laboratory, 44 Lincoln's Inn Fields, London WC2A 3LY, UK. ${ }^{3}$ UCL Cancer Institute, Paul O'Gorman Building, Huntley St, London WC1E, UK.

\section{Authors' contribution}

DF and CW jointly co-authored, read and approved the final manuscript.

Received: 3 May 2012 Accepted: 3 May 2012

Published: 18 June 2012

\section{References}

1. Li P, Nijhawan D, Budihardjo I, Srinivasula SM, Ahmad M, Alnemri ES, Wang X: Cytochrome $\mathrm{c}$ and dATP-dependent formation of Apaf-1/caspase-9 complex initiates an apoptotic protease cascade. Cell 1997, 91(4):479-489.

2. Cipolat S, Rudka T, Hartmann D, Costa V, Serneels L, Craessaerts K, Metzger K, Frezza C, Annaert W, D'Adamio L, Derks C, Dejaegere T, Pellegrini L, D'Hooge R, Scorrano L, De Strooper B: Mitochondrial rhomboid PARL regulates cytochrome $c$ release during apoptosis via OPA1-dependent cristae remodeling. Cell 2006, 126(1):163-175.

3. Du C, Fang M, Li Y, Li L, Wang X: Smac, a mitochondrial protein that promotes cytochrome c-dependent caspase activation by eliminating IAP inhibition. Cell 2000, 102(1):33-42.

4. Joza N, Susin SA, Daugas E, Stanford WL, Cho SK, Li CY, Sasaki T, Elia AJ, Cheng HY, Ravagnan L, Ferri KF, Zamzami N, Wakeham A, Hakem R, Yoshida H, Kong YY, Mak TW, Zúñiga-Pflücker JC, Kroemer G, Penninger JM: Essential role of the mitochondrial apoptosis-inducing factor in programmed cell death. Nature 2001, 410(6828):549-554.

5. Susin SA, Lorenzo HK, Zamzami N, Marzo I, Snow BE, Brothers GM, Mangion J, Jacotot E, Costantini P, Loeffler M, Larochette N, Goodlett DR, Aebersold $\mathrm{R}$, Siderovski DP, Penninger JM, Kroemer G: Molecular characterization of mitochondrial apoptosis-inducing factor. Nature 1999, 397(6718):441-446.

6. Martin SJ, Green DR: Protease activation during apoptosis: death by a thousand cuts? Cell 1995, 82(3):349-352.

7. Antonsson B, Montessuit S, Lauper S, Eskes R, Martinou JC: Bax oligomerization is required for channel-forming activity in liposomes and to trigger cytochrome c release from mitochondria. Biochem J 2000 2:271-278.

8. Chittenden T, Harrington EA, O'Connor R, Flemington C, Lutz RJ, Evan Gl, Guild BC: Induction of apoptosis by the $\mathrm{Bcl}-2$ homologue Bak. Nature 1995, 374(6524):733-736.

9. Wei MC, Zong WX, Cheng EH, Lindsten T, Panoutsakopoulou V, Ross AJ, Roth KA, MacGregor GR, Thompson CB, Korsmeyer SJ: Proapoptotic BAX and BAK: a requisite gateway to mitochondrial dysfunction and death. Science 2001, 292(5517):727-730.

10. Dai H, Smith A, Meng XW, Schneider PA, Pang YP, Kaufmann SH: Transient binding of an activator $\mathrm{BH} 3$ domain to the $\mathrm{Bak} \mathrm{BH} 3$-binding groove initiates Bak oligomerization. J Cell Biol 2011, 194(1):39-48.

11. Dewson G, Kratina T, Czabotar P, Day CL, Adams JM, Kluck RM: Bak activation for apoptosis involves oligomerization of dimers via their alpha6 helices. Mol Cell 2009, 36(4):696-703.

12. Eskes R, Desagher $S$, Antonsson B, Martinou JC: Bid induces the oligomerization and insertion of Bax into the outer mitochondrial membrane. Mol Cell Biol 2000, 20(3):929-935.
13. Roucou X, Montessuit S, Antonsson B, Martinou JC: Bax oligomerization in mitochondrial membranes requires tBid (caspase-8-cleaved Bid) and a mitochondrial protein. Biochem J 2002, 368(Pt 3):915-921.

14. Ren D, Tu HC, Kim H, Wang GX, Bean GR, Takeuchi O, Jeffers JR, Zambetti GP, Hsieh JJ, Cheng EH: BID, BIM, and PUMA are essential for activation of the BAX- and BAK-dependent cell death program. Science 2010, 330 (6009):1390-1393.

15. Kim H, Tu HC, Ren D, Takeuchi O, Jeffers JR, Zambetti GP, Hsieh JJ, Cheng EH: Stepwise activation of BAX and BAK by tBID, BIM, and PUMA initiates mitochondrial apoptosis. Mol Cell 2009, 36(3):487-499.

16. Ley R, Balmanno K, Hadfield K, Weston C, Cook SJ: Activation of the ERK1/2 signaling pathway promotes phosphorylation and proteasomedependent degradation of the BH3-only protein, Bim. J Biol Chem 2003, 278(21):18811-18816.

17. Biswas SC, Greene LA: Nerve growth factor (NGF) down-regulates the $\mathrm{BCl}-2$ homology $3(\mathrm{BH} 3)$ domain-only protein Bim and suppresses its proapoptotic activity by phosphorylation. J Biol Chem 2002, 277 (51):49511-49516.

18. Ley R, Ewings KE, Hadfield K, Howes E, Balmanno K, Cook SJ: Extracellular signal-regulated kinases $1 / 2$ are serum-stimulated "Bim(EL) kinases" that bind to the $\mathrm{BH} 3$-only protein Bim(EL) causing its phosphorylation and turnover. J Biol Chem 2004, 279(10):8837-8847.

19. Luciano F, Jacquel A, Colosetti P, Herrant M, Cagnol S, Pages G, Auberger P: Phosphorylation of Bim-EL by Erk1/2 on serine 69 promotes its degradation via the proteasome pathway and regulates its proapoptotic function. Oncogene 2003, 22(43):6785-6793.

20. Yin XM, Wang K, Gross A, Zhao Y, Zinkel S, Klocke B, Roth KA, Korsmeyer SJ: Bid-deficient mice are resistant to Fas-induced hepatocellular apoptosis. Nature 1999, 400(6747):886-891.

21. Nakano K, Vousden KH: PUMA, a novel proapoptotic gene, is induced by p53. Mol Cell 2001, 7(3):683-694.

22. Reed JC, Cuddy M, Slabiak T, Croce CM, Nowell PC: Oncogenic potential of bcl-2 demonstrated by gene transfer. Nature 1988, 336(6196):259-261.

23. Boise LH, Gonzalez-Garcia M, Postema CE, Ding L, Lindsten T, Turka LA, Mao X, Nuñez G, Thompson CB: bcl-x, a bcl-2-related gene that functions as a dominant regulator of apoptotic cell death. Cell 1993, 74(4):597-608.

24. Oltvai ZN, Milliman CL, Korsmeyer SJ: Bcl-2 heterodimerizes in vivo with a conserved homolog, Bax, that accelerates programmed cell death. Cell 1993, 74(4):609-619.

25. Reynolds JE, Yang T, Qian L, Jenkinson JD, Zhou P, Eastman A, Craig RW: $\mathrm{Mcl}-1$, a member of the $\mathrm{Bcl}-2$ family, delays apoptosis induced by c-Myc overexpression in Chinese hamster ovary cells. Cancer Res 1994, 54 (24):6348-6352.

26. Beroukhim R, Mermel CH, Porter D, Wei G, Raychaudhuri S, Donovan J, Barretina J, Boehm JS, Dobson J, Urashima M: Mc Henry KT, Pinchback RM, Ligon AH, Cho YJ, Haery L, Greulich H, Reich M, Winckler W, Lawrence MS, Weir BA, Tanaka KE, Chiang DY, Bass AJ, Loo A, Hoffman C, Prensner J, Liefeld T, Gao $Q$, Yecies D, Signoretti S, et al: The landscape of somatic copy-number alteration across human cancers. Nature 2010, 463(7283):899-905.

27. Fanidi A, Harrington EA, Evan Gl: Cooperative interaction between c-myc and bcl-2 proto-oncogenes. Nature 1992, 359(6395):554-556.

28. Hueber AO, Zornig M, Lyon D, Suda T, Nagata S, Evan Gl: Requirement for the CD95 receptor-ligand pathway in c-Myc-induced apoptosis. Science 1997, 278(5341):1305-1309.

29. Elgendy M, Sheridan C, Brumatti G, Martin SJ: Oncogenic Ras-induced expression of Noxa and Beclin-1 promotes autophagic cell death and limits clonogenic survival. Mol Cell 2011, 42(1):23-35.

30. Certo M: Del Gaizo Moore V, Nishino M, Wei G, Korsmeyer S, Armstrong SA, Letai A: Mitochondria primed by death signals determine cellular addiction to antiapoptotic BCL-2 family members. Cancer Cell 2006, 9(5):351-365.

31. Letai A, Bassik MC, Walensky LD, Sorcinelli MD, Weiler S, Korsmeyer SJ: Distinct $\mathrm{BH} 3$ domains either sensitize or activate mitochondrial apoptosis, serving as prototype cancer therapeutics. Cancer Cell 2002, 2(3):183-192.

32. Kuwana T, Bouchier-Hayes L, Chipuk JE, Bonzon C, Sullivan BA, Green DR, Newmeyer DD: $\mathrm{BH} 3$ domains of $\mathrm{BH} 3$-only proteins differentially regulate Bax-mediated mitochondrial membrane permeabilization both directly and indirectly. Mol Cell 2005, 17(4):525-535.

33. Chen L, Willis SN, Wei A, Smith BJ, Fletcher JI, Hinds MG, Colman PM, Day $\mathrm{CL}$, Adams JM, Huang DC: Differential targeting of prosurvival Bcl-2 proteins by their $\mathrm{BH} 3$-only ligands allows complementary apoptotic function. Mol Cell 2005, 17(3):393-403. 
34. Tse C, Shoemaker AR, Adickes J, Anderson MG, Chen J, Jin S, Johnson EF, Marsh KC, Mitten MJ, Nimmer P, Roberts L, Tahir SK, Xiao Y, Yang X, Zhang H, Fesik S, Rosenberg SH, Elmore SW: ABT-263: a potent and orally bioavailable Bcl-2 family inhibitor. Cancer Res 2008, 68(9):3421-3428.

35. Oltersdorf T, Elmore SW, Shoemaker AR, Armstrong RC, Augeri DJ, Belli BA, Bruncko M, Deckwerth TL, Dinges J, Hajduk PJ, Joseph MK, Kitada S, Korsmeyer SJ, Kunzer AR, Letai A, Li C, Mitten MJ, Nettesheim DG, Ng S, Nimmer PM, O'Connor JM, Oleksijew A, Petros AM, Reed JC, Shen W, Tahir SK, Thompson CB, Tomaselli KJ, Wang B, Wendt MD, et al: An inhibitor of Bcl-2 family proteins induces regression of solid tumours. Nature 2005, 435(7042):677-681.

36. Shoemaker AR, Mitten MJ, Adickes J, Ackler S, Refici M, Ferguson D, Oleksijew A, O'Connor JM, Wang B, Frost DJ, Bauch J, Marsh K, Tahir SK, Yang X, Tse C, Fesik SW, Rosenberg SH, Elmore SW: Activity of the Bcl-2 family inhibitor ABT-263 in a panel of small cell lung cancer xenograft models. Clin Cancer Res 2008, 14(11):3268-3277.

37. Gandhi L, Camidge DR: Ribeiro De Oliveira M, Bonomi P, Gandara D, Khaira D, Hann CL, McKeegan EM, Litvinovich E, Hemken PM, Dive C, Enschede SH, Nolan C, Chiu YL, Busman T, Xiong H, Krivoshik AP, Humerickhouse R, Shapiro Gl, Rudin CM: Phase I study of Navitoclax (ABT-263), a novel Bcl-2 family inhibitor, in patients with small-cell lung cancer and other solid tumors. J Clin Oncol 2011, 29(7):909-916.

38. Chen S, Dai Y, Harada H, Dent P, Grant S: Mcl-1 down-regulation potentiates ABT-737 lethality by cooperatively inducing Bak activation and Bax translocation. Cancer Res 2007, 67(2):782-791.

39. Lin X, Morgan-Lappe S, Huang X, Li L, Zakula DM, Vernetti LA, Fesik SW, Shen $Y$ : 'Seed' analysis of off-target siRNAs reveals an essential role of $\mathrm{Mcl}-1$ in resistance to the small-molecule $\mathrm{Bcl}-2 / \mathrm{Bcl}-\mathrm{XL}$ inhibitor ABT-737. Oncogene 2007, 26(27):3972-3979.

40. van Delft MF, Wei AH, Mason KD, Vandenberg CJ, Chen L, Czabotar PE, Willis SN, Scott CL, Day CL, Cory S, Adams JM, Roberts AW, Huang DC: The BH3 mimetic $A B T-737$ targets selective $B C l-2$ proteins and efficiently induces apoptosis via Bak/Bax if Mcl-1 is neutralized. Cancer Cell 2006, 10(5):389-399.

41. Hauck P, Chao BH, Litz J, Krystal GW: Alterations in the Noxa/Mcl-1 axis determine sensitivity of small cell lung cancer to the $\mathrm{BH} 3$ mimetic ABT-737. Mol Cancer Ther 2009, 8(4):883-892.

42. Yecies D, Carlson NE, Deng J, Letai A: Acquired resistance to ABT-737 in lymphoma cells that up-regulate MCL-1 and BFL-1. Blood 2010, 115 (16):3304-3313.

43. Tahir SK, Wass J, Joseph MK, Devanarayan V, Hessler P, Zhang H, Elmore SW, Kroeger PE, Tse C, Rosenberg SH, Anderson MG: Identification of expression signatures predictive of sensitivity to the Bcl-2 family member inhibitor ABT-263 in small cell lung carcinoma and leukemia/ lymphoma cell lines. Mol Cancer Ther 2010, 9(3):545-557.

44. Jacks T, Weinberg RA: Taking the study of cancer cell survival to a new dimension. Cell 2002, 111(7):923-925.

45. Yang TM, Barbone D, Fennell DA, Broaddus VC: BCl-2 family proteins contribute to apoptotic resistance in lung cancer multicellular spheroids. Am J Respir Cell Mol Biol 2009, 41(1):14-23.

46. Barbone D, Ryan JA, Kolhatkar N, Chacko AD, Jablons DM, Sugarbaker DJ, Bueno R, Letai AG, Coussens LM, Fennell DA, Broaddus VC: The Bcl-2 repertoire of mesothelioma spheroids underlies acquired apoptotic multicellular resistance. Cell Death Dis 2011, 2:e174.

47. Seward RJ, von Haller PD, Aebersold R, Huber BT: Phosphorylation of the pro-apoptotic protein Bim in lymphocytes is associated with protection from apoptosis. Mol Immunol 2003, 39(16):983-993.

48. Hubner A, Barrett T, Flavell RA, Davis RJ: Multisite phosphorylation regulates Bim stability and apoptotic activity. Mol Cell 2008, 30(4):415-425.

49. O'Reilly LA, Kruse EA, Puthalakath H, Kelly PN, Kaufmann T, Huang DC, Strasser A: MEK/ERK-mediated phosphorylation of Bim is required to ensure survival of $\mathrm{T}$ and $\mathrm{B}$ lymphocytes during mitogenic stimulation. $J$ Immunol 2009, 183(1):261-269.

50. Harada H, Quearry B, Ruiz-Vela A, Korsmeyer SJ: Survival factor-induced extracellular signal-regulated kinase phosphorylates BIM, inhibiting its association with BAX and proapoptotic activity. Proc Natl Acad Sci USA 2004, 101(43):15313-15317.

51. Zha J, Harada H, Yang E, Jockel J, Korsmeyer SJ: Serine phosphorylation of death agonist $B A D$ in response to survival factor results in binding to 14-3-3 not BCL-X(L). Cell 1996, 87(4):619-628.

52. Druker BJ, Tamura S, Buchdunger E, Ohno S, Segal GM, Fanning S, Zimmermann J, Lydon NB: Effects of a selective inhibitor of the Abl tyrosine kinase on the growth of Bcr-Abl positive cells. Nat Med 1996, 2(5):561-566.
53. Druker BJ, Sawyers CL, Kantarjian H, Resta DJ, Reese SF, Ford JM, Capdeville $R$, Talpaz M: Activity of a specific inhibitor of the BCR-ABL tyrosine kinase in the blast crisis of chronic myeloid leukemia and acute lymphoblastic leukemia with the Philadelphia chromosome. N Engl J Med 2001, 344 (14):1038-1042.

54. Druker BJ, Talpaz M, Resta DJ, Peng B, Buchdunger E, Ford JM, Lydon NB, Kantarjian H, Capdeville R, Ohno-Jones S, Sawyers CL: Efficacy and safety of a specific inhibitor of the BCR-ABL tyrosine kinase in chronic myeloid leukemia. N Engl J Med 2001, 344(14):1031-1037.

55. Kuroda J, Puthalakath $H$, Cragg MS, Kelly PN, Bouillet P, Huang DC, Kimura S, Ottmann OG, Druker BJ, Villunger A, Roberts AW, Strasser A: Bim and Bad mediate imatinib-induced killing of $\mathrm{Bcr} / \mathrm{Abl}+$ leukemic cells, and resistance due to their loss is overcome by a $\mathrm{BH} 3$ mimetic. Proc Natl Acad Sci USA 2006, 103(40):14907-14912.

56. Schiller JH, Harrington D, Belani CP, Langer C, Sandler A, Krook J, Zhu J, Johnson DH: Eastern Cooperative Oncology Group: Comparison of four chemotherapy regimens for advanced non-small-cell lung cancer. $N$ Engl $J$ Med 2002, 346(2):92-98

57. Sandler A, Gray R, Perry MC, Brahmer J, Schiller JH, Dowlati A, Lilenbaum R, Johnson DH: Paclitaxel-carboplatin alone or with bevacizumab for nonsmall-cell lung cancer. N Engl J Med 2006, 355(24):2542-2550.

58. Pirker R, Pereira JR, Szczesna A, von Pawel J, Krzakowski M, Ramlau R, Vynnychenko I, Park K, Yu CT, Ganul V, Roh JK, Bajetta E, O'Byrne K, de Marinis F, Eberhardt W, Goddemeier T, Emig M, Gatzemeier U: FLEX Study Team: Cetuximab plus chemotherapy in patients with advanced nonsmall-cell lung cancer (FLEX): an open-label randomised phase III trial. Lancet 2009, 373(9674):1525-1531

59. Tsao MS, Sakurada A, Cutz JC, Zhu CQ, Kamel-Reid S, Squire J, Lorimer I, Zhang T, Liu N, Daneshmand M, Marrano P: da Cunha Santos G, Lagarde A, Richardson F, Seymour L, Whitehead M, Ding K, Pater J, Shepherd FA: Erlotinib in lung cancer - molecular and clinical predictors of outcome. $N$ Engl J Med 2005, 353(2):133-144.

60. Shepherd FA, Pereira JR, Ciuleanu T, Tan EH, Hirsh V, Thongprasert S, Campos D, Maoleekoonpiroj S, Smylie M, Martins R, van Kooten M, Dediu M, Findlay B, Tu D, Johnston D, Bezjak A, Clark G, Santabárbara P, Seymour L: National Cancer Institute of Canada Clinical Trials Group: Erlotinib in previously treated non-small-cell lung cancer. N Engl J Med 2005, 353 (2):123-132.

61. Giaccone G, Herbst RS, Manegold C, Scagliotti G, Rosell R, Miller V, Natale RB, Schiller JH, Von Pawel J, Pluzanska A, Gatzemeier U, Grous J, Ochs JS, Averbuch SD, Wolf MK, Rennie P, Fandi A, Johnson DH: Gefitinib in combination with gemcitabine and cisplatin in advanced non-small-cell lung cancer: a phase III trial-INTACT 1. J Clin Oncol 2004, 22(5):777-784.

62. Herbst RS, Giaccone G, Schiller JH, Natale RB, Miller V, Manegold C, Scagliotti G, Rosell R, Oliff I, Reeves JA, Wolf MK, Krebs AD, Averbuch SD, Ochs JS, Grous J, Fandi A, Johnson DH: Gefitinib in combination with paclitaxel and carboplatin in advanced non-small-cell lung cancer: a phase III trialINTACT 2. J Clin Oncol 2004, 22(5):785-794.

63. Herbst RS, Prager D, Hermann R, Fehrenbacher L, Johnson BE, Sandler A, Kris MG, Tran HT, Klein P, Li X, Ramies D, Johnson DH, Miller VA: TRIBUTE Investigator Group: TRIBUTE: a phase III trial of erlotinib hydrochloride (OSI-774) combined with carboplatin and paclitaxel chemotherapy in advanced non-small-cell lung cancer. J Clin Oncol 2005, 23(25):5892-5899.

64. Gatzemeier U, Pluzanska A, Szczesna A, Kaukel E, Roubec J, De Rosa F, Milanowski J, Karnicka-Mlodkowski H, Pesek M, Serwatowski P, Ramlau R, Janaskova T, Vansteenkiste J, Strausz J, Manikhas GM, Von Pawel J: Phase III study of erlotinib in combination with cisplatin and gemcitabine in advanced non-small-cell lung cancer: the Tarceva Lung Cancer Investigation Trial. J Clin Oncol 2007, 25(12):1545-1552

65. Paez JG, Janne PA, Lee JC, Tracy S, Greulich H, Gabriel S, Herman P, Kaye FJ, Lindeman N, Boggon TJ, Naoki K, Sasaki H, Fujii Y, Eck MJ, Sellers WR, Johnson BE, Meyerson M: EGFR mutations in lung cancer: correlation with clinical response to gefitinib therapy. Science 2004, 304(5676):1497-1500.

66. Lynch TJ, Bell DW, Sordella R, Gurubhagavatula S, Okimoto RA, Brannigan BW, Harris PL, Haserlat SM, Supko JG, Haluska FG, Louis DN, Christiani DC Settleman J, Haber DA: Activating mutations in the epidermal growth factor receptor underlying responsiveness of non-small-cell lung cancer to gefitinib. N Engl J Med 2004, 350(21):2129-2139.

67. Pao W, Miller V, Zakowski M, Doherty J, Politi K, Sarkaria I, Singh B, Heelan R, Rusch V, Fulton L, Mardis E, Kupfer D, Wilson R, Kris M, Varmus H: EGF receptor gene mutations are common in lung cancers from "never 
smokers" and are associated with sensitivity of tumors to gefitinib and erlotinib. Proc Natl Acad Sci USA 2004, 101(36):13306-13311.

68. Mok TS, Wu YL, Thongprasert S, Yang CH, Chu DT, Saijo N, Sunpaweravong P, Han B, Margono B, Ichinose Y, Nishiwaki Y, Ohe Y, Yang JJ,

Chewaskulyong B, Jiang $H$, Duffield EL, Watkins CL, Armour AA, Fukuoka M: Gefitinib or carboplatin-paclitaxel in pulmonary adenocarcinoma. N Engl J Med 2009, 361(10):947-957.

69. Maemondo M, Inoue A, Kobayashi K, Sugawara S, Oizumi S, Isobe H, Gemma A, Harada M, Yoshizawa H, Kinoshita I, Fujita Y, Okinaga S, Hirano H, Yoshimori K, Harada T, Ogura T, Ando M, Miyazawa H, Tanaka T, Saijo Y, Hagiwara K, Morita S, Nukiwa T: North-East Japan Study Group: Gefitinib or chemotherapy for non-small-cell lung cancer with mutated EGFR. $N$ Engl J Med 2010, 362(25):2380-2388.

70. Rosell R, Moran T, Queralt C, Porta R, Cardenal F, Camps C, Majem M, LopezVivanco G, Isla D, Provencio M, Insa A, Massuti B, Gonzalez-Larriba JL, PazAres L, Bover I, Garcia-Campelo R, Moreno MA, Catot S, Rolfo C, Reguart N, Palmero R, Sánchez JM, Bastus R, Mayo C, Bertran-Alamillo J, Molina MA, Sanchez JJ, Taron M: Spanish Lung Cancer Group: Screening for epidermal growth factor receptor mutations in lung cancer. $N$ Engl J Med 2009, 361(10):958-967.

71. Sordella R, Bell DW, Haber DA, Settleman J: Gefitinib-sensitizing EGFR mutations in lung cancer activate anti-apoptotic pathways. Science 2004, 305(5687):1163-1167.

72. Yun CH, Boggon TJ, Li Y, Woo MS, Greulich H, Meyerson M, Eck MJ: Structures of lung cancer-derived EGFR mutants and inhibitor complexes: mechanism of activation and insights into differential inhibitor sensitivity. Cancer Cell 2007, 11(3):217-227.

73. Tracy S, Mukohara T, Hansen M, Meyerson M, Johnson BE, Janne PA: Gefitinib induces apoptosis in the EGFRL858R non-small-cell lung cancer cell line H3255. Cancer Res 2004, 64(20):7241-7244.

74. Kuribara R, Honda H, Matsui H, Shinjyo T, Inukai T, Sugita K, Nakazawa S, Hirai H, Ozawa K, Inaba T: Roles of Bim in apoptosis of normal and BcrAbl-expressing hematopoietic progenitors. Mol Cell Biol 2004, 24(14):6172-6183.

75. Cragg MS, Kuroda J, Puthalakath H, Huang DC, Strasser A: Gefitinib-induced killing of NSCLC cell lines expressing mutant EGFR requires BIM and can be enhanced by BH3 mimetics. PLOS Med 2007, 4(10):1681-1689. discussion 1690.

76. Costa DB, Halmos B, Kumar A, Schumer ST, Huberman MS, Boggon TJ, Tenen DG, Kobayashi S: BIM mediates EGFR tyrosine kinase inhibitorinduced apoptosis in lung cancers with oncogenic EGFR mutations. PLOS Med 2007, 4(10):1669-1679. discussion 1680

77. Gong Y, Somwar R, Politi K, Balak M, Chmielecki J, Jiang X, Pao W: Induction of BIM is essential for apoptosis triggered by EGFR kinase inhibitors in mutant EGFR-dependent lung adenocarcinomas. PLoS Med 2007, 4(10): e294.

78. Deng J, Shimamura T, Perera S, Carlson NE, Cai D, Shapiro Gl, Wong KK, Letai A: Proapoptotic BH3-only BCL-2 family protein BIM connects death signaling from epidermal growth factor receptor inhibition to the mitochondrion. Cancer Res 2007, 67(24):11867-11875.

79. Takezawa K, Okamoto I, Nishio K, Janne PA, Nakagawa K: Role of ERK-BIM and STAT3-survivin signaling pathways in ALK inhibitor-induced apoptosis in EML4-ALK-positive lung cancer. Clin Cancer Res 2011, 17 (8):2140-2148

80. Kwak EL, Bang YJ, Camidge DR, Shaw AT, Solomon B, Maki RG, Ou SH, Dezube BJ, Jänne PA, Costa DB, Varella-Garcia M, Kim WH, Lynch TJ, Fidias P, Stubbs H, Engelman JA, Sequist LV, Tan W, Gandhi L, Mino-Kenudson M, Wei GC, Shreeve SM, Ratain MJ, Settleman J, Christensen JG, Haber DA, Wilner K, Salgia R, Shapiro Gl, Clark JW, et al: Anaplastic lymphoma kinase inhibition in non-small-cell lung cancer. N Engl J Med 2010, 363(18):1693-1703.

81. Pao W, Miller VA, Politi KA, Riely GJ, Somwar R, Zakowski MF, Kris MG, Varmus $\mathrm{H}$ : Acquired resistance of lung adenocarcinomas to gefitinib or erlotinib is associated with a second mutation in the EGFR kinase domain. PLoS Med 2005, 2(3):e73.

82. Kobayashi S, Boggon TJ, Dayaram T, Janne PA, Kocher O, Meyerson M, Johnson BE, Eck MJ, Tenen DG, Halmos B: EGFR mutation and resistance of non-small-cell lung cancer to gefitinib. N Engl J Med 2005, 352(8):786-792.

83. Bell DW, Gore I, Okimoto RA, Godin-Heymann N, Sordella R, Mulloy R, Sharma SV, Brannigan BW, Mohapatra G, Settleman J, Haber DA: Inherited susceptibility to lung cancer may be associated with the T790M drug resistance mutation in EGFR. Nat Genet 2005, 37(12):1315-1316.
84. Vikis $H$, Sato $M$, James $M$, Wang D, Wang $Y$, Wang M, Jia D, Liu Y, BaileyWilson JE, Amos Cl, Pinney SM, Petersen GM, de Andrade M, Yang P, Wiest JS, Fain PR, Schwartz AG, Gazdar A, Gaba C, Rothschild H, Mandal D, Kupert E, Seminara D, Viswanathan A, Govindan R, Minna J, Anderson MW, You M: EGFR-T790M is a rare lung cancer susceptibility allele with enhanced kinase activity. Cancer Res 2007, 67(10):4665-4670.

85. Inukai M, Toyooka S, Ito S, Asano H, Ichihara S, Soh J, Suehisa H, Ouchida M, Aoe K, Aoe M, Kiura K, Shimizu N, Date H: Presence of epidermal growth factor receptor gene T790M mutation as a minor clone in non-small cell lung cancer. Cancer Res 2006, 66(16):7854-7858.

86. Rosell R, Molina MA, Costa C, Simonetti S, Gimenez-Capitan A, BertranAlamillo J, Mayo C, Moran T, Mendez P, Cardenal F, Isla D, Provencio M, Cobo M, Insa A, Garcia-Campelo R, Reguart N, Majem M, Viteri S, Carcereny E, Porta R, Massuti B, Queralt C, de Aguirre I, Sanchez JM, Sanchez-Ronco M, Mate JL, Ariza A, Benlloch S, Sanchez JJ, Bivona TG, et al: Pretreatment EGFR T790M mutation and BRCA1 mRNA expression in erlotinib-treated advanced non-small-cell lung cancer patients with EGFR mutations. Clin Cancer Res 2011, 17(5):1160-1168

87. Sequist $L V$, Waltman BA, Dias-Santagata D, Digumarthy $S$, Turke AB, Fidias $P$, Bergethon K, Shaw AT, Gettinger S, Cosper AK, Akhavanfard S, Heist RS, Temel J, Christensen JG, Wain JC, Lynch TJ, Vernovsky K, Mark EJ, Lanuti M, lafrate AJ, Mino-Kenudson M, Engelman JA: Genotypic and histological evolution of lung cancers acquiring resistance to EGFR inhibitors. Sci Transl Med 2011, 3(75):75-26

88. Engelman JA, Zejnullahu K, Mitsudomi T, Song Y, Hyland C, Park JO, Lindeman N, Gale CM, Zhao X, Christensen J, Kosaka T, Holmes AJ, Rogers AM, Cappuzzo F, Mok T, Lee C, Johnson BE, Cantley LC, Jänne PA: MET amplification leads to gefitinib resistance in lung cancer by activating ERBB3 signaling. Science 2007, 316(5827):1039-1043.

89. Turke $A B$, Zejnullahu $K$, Wu YL, Song $Y$, Dias-Santagata $D$, Lifshits E, Toschi $L$, Rogers A, Mok T, Sequist L, Lindeman NI, Murphy C, Akhavanfard S, Yeap BY, Xiao Y, Capelletti M, lafrate AJ, Lee C, Christensen JG, Engelman JA, Jänne PA: Preexistence and clonal selection of MET amplification in EGFR mutant NSCLC. Cancer Cell 2010, 17(1):77-88.

90. Cappuzzo F, Janne PA, Skokan M, Finocchiaro G, Rossi E, Ligorio C, Zucali PA, Terracciano L, Toschi L, Roncalli M, Destro A, Incarbone M, Alloisio M, Santoro A, Varella-Garcia M: MET increased gene copy number and primary resistance to gefitinib therapy in non-small-cell lung cancer patients. Ann Oncol 2009, 20(2):298-304.

91. Benedettini E, Sholl LM, Peyton M, Reilly J, Ware C, Davis L, Vena N, Bailey D, Yeap BY, Fiorentino M, Ligon AH, Pan BS, Richon V, Minna JD, Gazdar AF Draetta G, Bosari S, Chirieac LR, Lutterbach B, Loda M: Met activation in non-small cell lung cancer is associated with de novo resistance to EGFR inhibitors and the development of brain metastasis. Am J Pathol 2010 177(1):415-423.

92. Sos ML, Koker M, Weir BA, Heynck S, Rabinovsky R, Zander T, Seeger JM, Weiss J, Fischer F, Frommolt P, Michel K, Peifer M, Mermel C, Girard L, Peyton M, Gazdar AF, Minna JD, Garraway LA, Kashkar H, Pao W, Meyerson M, Thomas RK: PTEN loss contributes to erlotinib resistance in EGFR-mutant lung cancer by activation of Akt and EGFR. Cancer Res 2009, 69(8):3256-3261.

93. Wang SE, Narasanna A, Perez-Torres M, Xiang B, Wu FY, Yang S, Carpenter G, Gazdar AF, Muthuswamy SK, Arteaga CL: HER2 kinase domain mutation results in constitutive phosphorylation and activation of HER2 and EGFR and resistance to EGFR tyrosine kinase inhibitors. Cancer Cell 2006, 10(1):25-38.

94. Zhou W, Ercan D, Chen L, Yun CH, Li D, Capelletti M, Cortot AB, Chirieac L, lacob RE, Padera R, Engen JR, Wong KK, Eck MJ, Gray NS, Jänne PA: Novel mutant-selective EGFR kinase inhibitors against EGFR T790M. Nature 2009, 462(7276):1070-1074.

95. Faber AC, Li D, Song Y, Liang MC, Yeap BY, Bronson RT, Lifshits E, Chen Z, Maira SM, García-Echeverría C, Wong KK, Engelman JA: Differential induction of apoptosis in HER2 and EGFR addicted cancers following PI3K inhibition. Proc Natl Acad Sci USA 2009, 106(46):19503-19508.

96. Bivona TG, Hieronymus H, Parker J, Chang K, Taron M, Rosell R, Moonsamy P, Dahlman K, Miller VA, Costa C, Hannon G, Sawyers CL: FAS and NFkappaB signalling modulate dependence of lung cancers on mutant EGFR. Nature 2011, 471(7339):523-526.

97. 7Choi YL, Soda M, Yamashita Y, Ueno T, Takashima J, Nakajima T, Yatabe Y, Takeuchi K, Hamada T, Haruta H, Ishikawa Y, Kimura H, Mitsudomi T, Tanio Y, Mano H: ALK Lung Cancer Study Group: EML4-ALK mutations in lung cancer that confer resistance to ALK inhibitors. N Engl J Med 2010, 363 (18):1734-1739. 
98. Sasaki T, Okuda K, Zheng W, Butrynski J, Capelletti M, Wang L, Gray NS, Wilner K, Christensen JG, Demetri G, Shapiro GI, Rodig SJ, Eck MJ, Jänne PA The neuroblastoma-associated F1174L ALK mutation causes resistance to an ALK kinase inhibitor in ALK-translocated cancers. Cancer Res 2010, 70(24):10038-10043.

99. Katayama R, Khan TM, Benes C, Lifshits E, Ebi H, Rivera VM, Shakespeare WC, lafrate AJ, Engelman JA, Shaw AT: Therapeutic strategies to overcome crizotinib resistance in non-small cell lung cancers harboring the fusion oncogene EML4-ALK. Proc Natl Acad Sci USA 2011, 108(18):7535-7540,

100. Chen Z, Sasaki T, Tan X, Carretero J, Shimamura T, Li D, Xu C, Wang Y, Adelmant GO, Capelletti M, Lee HJ, Rodig SJ, Borgman C, Park SI, Kim HR, Padera R, Marto JA, Gray NS, Kung AL, Shapiro Gl, Jänne PA, Wong KK: Inhibition of ALK, PI3K/MEK, and HSP90 in murine lung adenocarcinoma induced by EML4-ALK fusion oncogene. Cancer Res 2010, 70(23):9827-9836.

101. Normant E, Paez G, West KA, Lim AR, Slocum KL, Tunkey C, McDougall J, Wylie AA, Robison K, Caliri K, Palombella VJ, Fritz CC: The Hsp90 inhibitor IPI-504 rapidly lowers EML4-ALK levels and induces tumor regression in ALK-driven NSCLC models. Oncogene 2011, 30(22):2581-2586.

102. Sakamoto H, Tsukaguchi T, Hiroshima S, Kodama T, Kobayashi T, Fukami TA, Oikawa N, Tsukuda T, Ishii N, Aoki Y: CH5424802, a selective ALK inhibitor capable of blocking the resistant gatekeeper mutant. Cancer Cell 2011, 19 (5):679-690.

103. Stephens P, Hunter C, Bignell G, Edkins S, Davies H, Teague J, Stevens C O'Meara S, Smith R, Parker A, Barthorpe A, Blow M, Brackenbury L, Butler A, Clarke O, Cole J, Dicks E, Dike A, Drozd A, Edwards K, Forbes S, Foster R, Gray K, Greenman C, Halliday K, Hills K, Kosmidou V, Lugg R, Menzies A, Perry J, et al: Lung cancer: intragenic ERBB2 kinase mutations in tumours. Nature 2004, 431(7008):525-526.

104. Minami Y, Shimamura T, Shah K, LaFramboise T, Glatt KA, Liniker E, Borgman CL, Haringsma HJ, Feng W, Weir BA, Lowell AM, Lee JC, Wolf J, Shapiro Gl, Wong KK, Meyerson M, Thomas RK: The major lung cancer-derived mutants of ERBB2 are oncogenic and are associated with sensitivity to the irreversible EGFR/ERBB2 inhibitor HKI-272. Oncogene 2007, 26 (34):5023-5027.

105. Ji H, Ramsey MR, Hayes DN, Fan C, McNamara K, Kozlowski P, Torrice C, Wu MC, Shimamura T, Perera SA, Liang MC, Cai D, Naumov GN, Bao L, Contreras CM, Li D, Chen L, Krishnamurthy J, Koivunen J, Chirieac LR, Padera RF, Bronson RT, Lindeman NI, Christiani DC, Lin X, Shapiro Gl, Jänne PA, Johnson BE, Meyerson M, Kwiatkowski DJ, et al: LKB1 modulates lung cancer differentiation and metastasis. Nature 2007, 448(7155):807-810

106. Pao W, Kris MG, lafrate AJ, Ladanyi M, Janne PA, Wistuba II, Miake-Lye R, Herbst $\mathrm{RS}$, Carbone DP, Johnson BE, Lynch TJ: Integration of molecular profiling into the lung cancer clinic. Clin Cancer Res 2009, 15(17):5317-5322.

107. Boisvert-Adamo K, Aplin AE: Mutant B-RAF mediates resistance to anoikis via Bad and Bim. Oncogene 2008, 27(23):3301-3312.

108. Wickenden JA, Jin H, Johnson M, Gillings AS, Newson C, Austin M, Chell SD, Balmanno K, Pritchard CA, Cook SJ: Colorectal cancer cells with the BRAF (V600E) mutation are addicted to the ERK1/2 pathway for growth factor-independent survival and repression of BIM. Oncogene 2008, 27 (57):7150-7161.

109. Paraiso KH, Xiang Y, Rebecca WW, Abel EV, Chen YA, Munko AC, Wood E, Fedorenko IV, Sondak VK, Anderson AR, Ribas A, Palma MD, Nathanson KL, Koomen JM, Messina JL, Smalley KS: PTEN loss confers BRAF inhibitor resistance to melanoma cells through the suppression of BIM expression. Cancer Res 2011, 71(7):2750-2760.

110. Tanizaki J, Okamoto I, Fumita S, Okamoto W, Nishio K, Nakagawa K: Roles of BIM induction and survivin downregulation in lapatinib-induced apoptosis in breast cancer cells with HER2 amplification. Oncogene 2011, 30(39):4097-4106.

111. Johnson L, Mercer K, Greenbaum D, Bronson RT, Crowley D, Tuveson DA Jacks T: Somatic activation of the K-ras oncogene causes early onset lung cancer in mice. Nature 2001, 410(6832):1111-1116.

112. Gysin S, Salt M, Young A, McCormick F: Therapeutic strategies for targeting ras proteins. Genes Cancer 2011, 2(3):359-372.

113. De Raedt T, Walton Z, Yecies JL, Li D, Chen Y, Malone CF, Maertens O, Jeong SM, Bronson RT, Lebleu V, Kalluri R, Normant E, Haigis MC, Manning $\mathrm{BD}$, Wong KK, Macleod KF, Cichowski K: Exploiting cancer cell vulnerabilities to develop a combination therapy for ras-driven tumors. Cancer Cell 2011, 20(3):400-413.

114. Sos ML, Michel K, Zander T, Weiss J, Frommolt P, Peifer M, Li D, Ullrich R, Koker M, Fischer F, Shimamura T, Rauh D, Mermel C, Fischer S, Stückrath I,
Heynck S, Beroukhim R, Lin W, Winckler W, Shah K, LaFramboise T, Moriarty WF, Hanna M, Tolosi L, Rahnenführer J, Verhaak R, Chiang D, Getz G, Hellmich $M$, Wolf J, et al: Predicting drug susceptibility of non-small cell lung cancers based on genetic lesions. J Clin Invest 2009, 119(6):1727-1740.

115. Barbie DA, Tamayo P, Boehm JS, Kim SY, Moody SE, Dunn IF, Schinzel AC, Sandy P, Meylan E, Scholl C, Fröhling S, Chan EM, Sos ML, Michel K, Mermel C, Silver SJ, Weir BA, Reiling JH, Sheng Q, Gupta PB, Wadlow RC, Le H, Hoersch S, Wittner BS, Ramaswamy S, Livingston DM, Sabatini DM, Meyerson M, Thomas RK, Lander ES, et al: Systematic RNA interference reveals that oncogenic KRAS-driven cancers require TBK1. Nature 2009, 462(7269):108-112.

116. Macconaill LE, Van Hummelen P, Meyerson M, Hahn WC: Clinical implementation of comprehensive strategies to characterize cancer genomes: opportunities and challenges. Cancer Discov 2011, 1(4):297.

117. Lee W, Jiang Z, Liu J, Haverty PM, Guan Y, Stinson J, Yue P, Zhang Y, Pant KP, Bhatt D, Ha C, Johnson S, Kennemer MI, Mohan S, Nazarenko I, Watanabe C, Sparks AB, Shames DS, Gentleman R, de Sauvage FJ, Stern H, Pandita A, Ballinger DG, Drmanac R, Modrusan Z, Seshagiri S, Zhang Z: The mutation spectrum revealed by paired genome sequences from a lung cancer patient. Nature 2010, 465(7297):473-477.

118. International Cancer Genome Consortium: Hudson TJ, Anderson W, Artez A, Barker AD, Bell C, Bernabe RR, Bhan MK, Calvo F, Eerola I, Gerhard DS, Guttmacher A, Guyer M, Hemsley FM, Jennings JL, Kerr D, Klatt P, Kolar P, Kusada J, Lane DP, Laplace F, Youyong L, Nettekoven G, Ozenberger B, Peterson J, Rao TS, Remacle J, Schafer AJ, Shibata T, Stratton MR, Vockley JG, et al: International network of cancer genome projects. Nature 2010, 464(7291):993-998.

doi:10.1186/1878-5085-3-6

Cite this article as: Fennell and Swanton: Unlocking Pandora's box: personalising cancer cell death in non-small cell lung cancer. The EPMA Journal 2012 3:6.

\section{Submit your next manuscript to BioMed Central and take full advantage of:}

- Convenient online submission

- Thorough peer review

- No space constraints or color figure charges

- Immediate publication on acceptance

- Inclusion in PubMed, CAS, Scopus and Google Scholar

- Research which is freely available for redistribution 